\title{
Speaking from above and below - The Gospel of John as metaphorical and narrative reference to a distant reality
}

\author{
Olivia Luisa Rahmsdorf \\ Johannes Gutenberg University, Mainz, Germany \\ o.rahmsdorf@uni-mainz.de
}

\begin{abstract}
The one who is from the earth belongs to the earth and speaks from the earth (Jn 3:31). How can one speak from the earth and at the same time about heavenly things? The Fourth Gospel (FG) creates a tension between these two realms of perception and cognition. To reach beyond or above the earth we have to transcend time and space, our individual context and limited visual horizon. To overcome the obstacle of confined space we can rely on metaphors since their key faculty is to transport ( $\mu \varepsilon \tau \alpha-$ $\varphi \dot{\varepsilon} \rho \omega)$. To transcend the limitations of time we can recruit the genre of narration. These two modes of references to a reality that is located and dated beyond our realms are at work in the FG. With Ricoeur's theoretical assistance, these features of the FG are highlighted as the prerequisite for its synthesis of the heterogeneous: above and below, light and darkness, spirit and flesh.
\end{abstract}

\section{Key words}

Gospel of John; Space and Time; Above and Below; Paul Ricoeur; Metaphors and Narratives

\section{From where do we speak?}

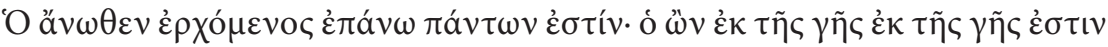

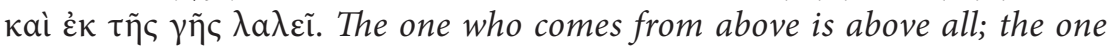
who is from the earth belongs to the earth and speaks from the earth (John 3:31).

It makes it easier, though sometimes less appealing to start an argument with a blatant distinction. As a matter of fact, John the Baptist articulates the above cited contrast between the one from above and the one from the 
earth in the beginning of the Fourth Gospel. Respectively, it will serve as a hermeneutical starting point to the following line of thought. John makes it perfectly clear: Our provenance or even current stand determines about what and in which way we will speak.

Especially in the Fourth Gospel, John the Baptist never gets tired to stress the most general difference in origin between him and the one he announces. Jesus, he insists earlier, is the one who comes after him, but has surpassed him because he was before him (John 1:15). These early statements of John the Baptist are, to be frank, rather irritating, especially if you are yourself from the earth, and speak from the earth, and perceive things in the regular categories of the earth that is: linear time and three-dimensional space. How can one person be coming after another but still surpass him and be before him? Without being able to fully grasp this riddle right now, we already get a glimpse of what it means to be from or not from the earth. This distinction is not only a spatial distinction, but it is also essentially a temporal one.

Now, where do we all speak from? In order for the reader to pick up where he or she stands some preliminary notes are necessary. This paper was held at a conference in Stellenbosch in May 2018 on the topic of Paul Ricoeur's famous question to his students: D'où parlez-vous? From where do you speak? Before the attendants and speakers of the conference came to Stellenbosch, they all knew that part of the answer to the shared question would entail the acknowledgement of a great variety and diversity in the presented points of view and points of speech. But, above all these differences - that was this paper's initial question - can we determine a shared point of speech?

Indeed, we, as we sat at the conference, or now write and read this paper, are all from the earth. This is one of the few determinations of origin that does not take any risk of being political insensitive. It is a rather unquestionable diagnosis that we are all from the earth, made out of the material, the soil of the earth, that we speak from an earthly vantage-point that we hear and feel and taste through our earthly senses and perceive the world in our earthly categories of perception.

But the author, for example, is not only from the earth and not from above, but from a particular region of this earth, from Europe, more particular from Germany, more particular from Mainz, more particular from a 
quarter called Gonsenheim etc. And not only is the author part of general history and not from eternity but the author was born in the postmodern era, in the $20^{\text {th }}$ century, in the year 1988, in the month August, on the $5^{\text {th }}$ day, at 6 o'clock in the morning and so on. We are all from the earth, but, below this most general unproblematic determination of origin, we can almost infinitely regress and differentiate our provenance, our roots and affiliations, up until the most particular points, that give us our individual identity. And somewhere along that road of further distinction we tend to articulate dichotomies, similar to the dichotomy of earth and above. We will articulate the things that separate us and therefore identify us. These dichotomies are in some way deduced from the rather general earth/ above distinction, but in many cases not less absolute and definite in their separating force. Sometimes they even sound just like the rather blatant description of John the Baptist: The one who comes from above is above all. The one who is from the earth belongs to the earth and speaks from the earth.

It seems like earth is earth and heaven is heaven, black is black and white is white, women are women and men are men, east is east and west is west, and never the twain shall meet, to quote the famous ballad of the British novelist Rudyard Kipling.

Below the most definite and shared belonging to the earth, there are millions of possible distinct and distant affiliations. The Gospel of John articulates many of these lower dichotomous distinctions: Those from Galilee and those from Judea, the Samaritans and the Jews, the Unbelievers and the Believers, the ones born from flesh and the ones born out of the spirit, the masters and slaves, the blind and the ones who see and many more. The Gospel has in fact been associated with the gnostic tradition because it employs so many dichotomies and shows dialectic tendencies (Bultmann 1959: 846-848). And parts of the Gospel have sadly been used by proApartheid exegetes, for example by Reverend WH du Plessis, who employed the story of the encounter of Jesus and the Samaritan women to legitimize ecclesiastical separation in white and non-white churches (Graeper [soon to be published]: 5-7). For our point of speech this seems to be a rather absurd utilization of the short story, which displays an encounter of two very distinct parties: women - man; Samaritan - Jew; sinner - sinless. We always predominantly or even exclusively perceived this story as a story 
aiming towards integration and unity and never perceived any segregating tendencies. But certainly, we have read it out of our very own context and along our individual hermeneutical horizon.

Interestingly enough, the contrasting aphorism of John the Baptist never found its way neither into biblical pro-apartheid argumentation nor into anti-apartheid argumentation.

Earth is earth and heaven is heaven, black is black and white is white, east is east and west and west, and never the twain shall meet? This paper proposes the opposite: In fact, the Gospel of John promotes a certain movement and encounter between diverse poles and we will attempt to describe how it does that. The Fourth Gospel conducts crossings. Not only from darkness to light, from Galilee to Judea, from Samaritans to Jews, from non-believers to believers, but the crossings go as far as to bridge the distance between the earthly realm and the heavenly. What is more, in and by this last surmounting of maximum distance, all other distances are automatically levelled out or suspended.

But how does the text of the Gospel transcend our - in theory impassable boundaries of earthly perception, interpretation und understanding? How does it enable us to view things from above, from a distant aerial perspective where tiny differences and contours become more and more irrelevant, where separating distances appear smaller and smaller? The Fourth Gospel is still 'only' a text, not an airplane, nor a spaceship, nor a medium for deification or a magic spell. How then does the Gospel orchestrate these crossings? Only by telling us and the Pharisee Nicodemus in the story that we need to be born from above $(\gamma \varepsilon v \nu \eta \theta \tilde{\eta} \ddot{\alpha} v \omega \theta \varepsilon v)$ in order to see the heavenly Kingdom of God (John 3:3)?

We will argue that the Gospel of John conducts these crossings not only by rhetorically commending or commanding them, but the possibilities of crossings are also performed by the text through language, more precisely through the instruments of genres, especially metaphors and narratives. Both these forms are employed to respond and resolve the rather dialectic genre of aphorisms on the other side, which are also included in the text. The different genres in the text interact with each other and through this interaction mediate the earthly, largely separating and classifying view, and the heavenly view, which transcends boundaries and differences. 
Through the text the recipient, who is from the earth, is picked up right where he stands and guided toward another destination.

As Harold Attridge described the Johannine trajectory: origin is not destiny (Attridge [soon to be published]: 26). Therefore, in modification of Kipling's poem and on basis of the Gospel's text, we suggest another ballad: Earth is earth and heaven is heaven and in God's spell (in the Gospel) the twain shall meet.

After this rather long hermeneutical placement and introduction, we will now first enlighten the theoretical background of metaphors and narratives as linguistic transporters and transcenders of distances with the help of Ricoeur's concept of the 'semantic innovation' (Ricoeur, 2009: $x$ ) and the 'synthesis of heterogeneous' (Ricoeur, 2009: ix). Then we will apply his theory to the Fourth Gospel's text, showing how the recipients of the text are on the one hand picked up right where they stand, and at the same time taken on a journey to get past the various limitations of their earthly origin.

\section{Ricoeur's theory: Language as a bridge}

In the first volume of Time and Narrative, Ricoeur starts with a comparison of metaphors and narratives as phenomena of 'semantic innovation'. "With metaphor, the innovation lies in the producing of a new semantic pertinence by means of an impertinent attribution" (Ricoeur, 2009: ix). The words used in a metaphor resist their normal usage and their literal interpretation and provoke a "displacement of meaning" (Ricoeur, 2009: ix), a shift, a transportation, "bringing together terms that at first seem 'distant', then suddenly 'close' (...) It is this change of distance in logical space that is the work of the productive imagination." (Ricoeur, 2009: x) Likewise Hans Blumenberg entrusted metaphors with "the transportation of the reflection on one object of intuition to another, quite different concept, to which perhaps no intuition can ever directly correspond." (Blumenberg, 2010: 4) To overcome the obstacle of confined space and limited visual horizon, we can rely on the linguistic instrument of metaphors, since their key faculty is to transport or transcend, as it is articulated in the Greek word $\mu \varepsilon \tau \alpha-$ $\varphi \dot{\varepsilon} \rho \omega=$ carry over, in German: 'über-tragen', in French: trans-poser. Spatial distances are bridged by metaphors. 
To transcend the limitations of time and its epistemological horizons, Ricoeur then recruits the genre of narratives. He detects a close connection between metaphors and narratives in their similar mode of reference: Just as the metaphor "brings to language aspects, qualities, and values of reality that lack access to language that is directly descriptive," the narrative executes the same metaphorical reference only in "application to the sphere of action" and its temporal values (Ricoeur, 2009: xi).

Both metaphors and narratives bring together what is distant and separate within the bounds of mere descriptive language, within the bound of time and space. The metaphor of the temple of the body in John 2:18-22, for example, brings together the cultural sphere of sacred architecture, the traditional Israelite interpretation of the temple as God's dwelling place, the physical, human appearance and fleshly existence of Jesus of Nazareth and the middle-platonic vision of the logos, who becomes flesh and 'camps' among us (John 1:14). Different social spheres such as history, religion, metaphysics, culture and philosophy are brought together in this metaphor and the huge distances, for example between the physical and metaphysical sphere, are bridged.

This metaphor of the bodily temple even becomes a micro-parable when Jesus commands his opponents to destroy the temple and forecasts that he will raise it within three days. ${ }^{1}$ Within this micro-narrative the unintelligible event of Jesus' death and resurrection is brought together with the historic event of the destruction of the temple - a "synthesis of heterogeneous". Similarly, the entire plot of the Gospel's narrative brings together disjointed or rather unrelated events and arranges them in a chronological and therewith causal or at least meaningful and coherent structure. Isolated events such as the wedding in Cana and the crucifixion scene are synthesized through overlapping characters (such as the mother), through related motifs such as water and wine/blood, through the role of the groom and the new accredited title "King of the Jews", and many more.

Therein, in the synthesis of heterogeneous, lies not only an epistemological chance to see new things, or rather old realities in a new light. Therein more over lies an ethical chance, namely to bring together what is in conflict, to

1 For further analysis of the micro-parable in John 2:19 see Popkes (2015: 711-718). 
experiment with differences and distances. As Ricoeur put it: "Literature is a vast laboratory in which we experiment with estimations, evaluations, and judgments of approval and condemnation through which narrativity serves as a propaedeutic to ethics." (Ricoeur, 1992: 115)

Literature does so by adapting unfamiliar material, new visions, foreign opinions in and through familiar forms and patterns, such as the generic formulas of narratives and metaphors. Only through a reduction of the formal complexity by genre is an acquaintance with new perspectives and unfamiliar aspects of reality possible. Only by balancing out redundancy and variation in the reception of a text a recipient is able to process new views that challenge his existing attitudes (Koschorke, 2013: 38-51). Metaphors and narratives, as we have learned from Ricoeur, help us bridge spatial as well as temporal gaps that divide us from others, our perspectives from other perspectives, our social spheres from other social spheres, our affiliations from other affiliations etc.

\section{Dialectic sententiae put into motion}

Let us turn to the Fourth Gospel's text. As noted earlier, the Gospel of John on the one hand consists of rather dialectic, divisive and rigid aphorisms, which are also called gnomes $(\gamma \nu \omega \dot{\omega} \mu)$ or sententiae and serve as prominent rhetoric devices in the early Roman Empire. And, on the other hand, the Gospel of John contains a rich network of metaphors and narrative interrelations, which are responding to the rigid oppositions displayed in the sententiae. The metaphors and narrative interrelations are setting these rather inflexible sententiae in motion: they are dynamizing them.

George Parsenios has analysed these sententiae in the Gospel of John. He defines a sententia as "a maxim that expresses some broadly held truth in a pithy, pointed style" (Parsenios 2010: 13). Later he examines that in these sententiae especially "social, cultural and religious divisions find their rhetorical expression." (Parsenios, 2010: 14) According to Parsenios the Johannine Jesus speaks in these sententiae, in order to associate himself with the people of spirit in contrast to the people of flesh. The profound difference between his use of sententiae and other usages is that the Gospel of John emphasizes the differences, but only in order to stress the necessity for the believers to cross from one pole to the other (Parsenios 2010: 24). 
Now, in addition to Parsenios' intriguing observation, this paper suggests that the Fourth Evangelist not only promotes these crossings but performs these crossings through language. He does so by balancing out established judgments and traditional beliefs with new perspectives and foreign phenomena through metaphorical and narrative transportation. This is particularly easy to observe when we focus on the temporal, spatial and causal composition of the Fourth Gospel. On the one hand the narrative as well as the employed metaphors work with and reassure temporal, spatial and causal linearity, on the other hand they disrupt or reverse this linearity (Estes 2008). We will demonstrate that with the help of two specific examples in the text: the healing-narrative of the man born blind in John 9:1-40 and the I-Am-Metaphor of Jesus within the narrative of the raising of Lazarus in John 11:1-45.

\section{The healing of the man born blind (John 9:1-40)}

The story of the healing of a man born blind is infused with sharp dichotomies on the one hand and dynamic crossings on the other. It begins with the first and most important dichotomy between sinners and those who give honour to God. The disciples ask Jesus in sight of a blind born beggar: Rabbi, who sinned, this man or his parents that he was born blind? (John 9:2) It is absolutely clear to the disciples that the fate of the blind man can be traced back to sinful behaviour, either his own or that of his parents. Jesus replies programmatically: Neither this man nor his parents sinned, but this happened so that the works of God might be displayed in him (v. 3). And he adds a sententious declaration: As long as it is day, we must do the works of him who sent me. Night is coming, when no one can work (v. 4). This sharp aphorism creates the feeling of the inevitable, the irreversible, the absolute fate.

At this point of the story we have already encountered the dichotomies of sin and godliness, night and day, being blind and seeing. The more players join the stage, the more dichotomies appear. The neighbours of the men born blind reduce him to his social rank as a beggar (v. 8), perhaps because they are beggars themselves and incredulously wonder how he could arrive at this new stage interacting with higher ranked people who are coming out of the temple. They ask him, where his healer is, but the beggar does not know. 
Next to appear are the Pharisees who introduce a temporal norm: the observance of the Shabbat as a criterion of being either a sinner or being from God (vv. 15-17). They do not trust the healed man who suddenly sees things and sees them anew, and they consequently do not trust his appraisal of Jesus as a prophet. They rather investigate on his provenance. They start to interrogate the parents of the man born blind (vv. 18-23).

His parents are acting according to another dichotomy: being within the synagogue or being thrown out of the community; being insiders or outsiders of an important social and religious sphere. This in-out-dichotomy is the crucial distinction that informs and instructs their behaviour. They won't tell the Pharisees anything about the healing because they fear becoming outsiders.

In the next round of inquiry the Pharisees again interrogate the man born blind: Is your healer a sinner? they ask him. The man born blind admits, that he does not know. He neither knows where his healer is (v.12), nor if he is a sinner (v. 25). What he knows, is that this man has healed him.

The Pharisees open a new dichotomous categorization: You are this fellow's disciple! We are disciples of Moses! We know that God spoke to Moses, but as for this fellow, we don't even know where he comes from (vv. 28-29). The Pharisees struggle with this new phenomenon of a healing of a man born blind, because they cannot trace it back to known origins and causes. Their stabilizing linearities are shaken. They seek rescue within stable affiliations and proveniences: They are disciples of Moses.

Responding to them, the healed man emphasizes the novelty of the recent events: Nobody has ever heard of opening the eyes of a man born blind (v. 32). And he connects exactly this newness to the descent from God: If this man were not from God, he could do nothing (v. 33)

The reader is guided through all these familiar dichotomies: sinfulness or godliness, beggar on the margins or public figure in the spotlight, breaker of religious norms or man from God, insider or outsider, follower of the one party or follower of the other. But the final attributions are rather ambiguous. Who is the sinner? In the course of the narrative this label is attributed first to the man born blind or to his parents (v. 2), then to Jesus as transgressor of the Shabbat (v. 16), then again to the man born blind (v. 34) (Parsenios 2010: 60). Finally, in the very end of this scene, Jesus articulates 
a rather complex verdict: For judgment I have come into this world, so that the blind will see and those who see will become blind (v. 39). The Pharisees then ask if he considers them blind, too, and Jesus replies: If you were blind, you would not be guilty of sin; but now that you claim you can see, your guilt remains (v. 42). The linearities are reversed: The one who is blind is not necessarily a sinner, rather the guilt remains with those who always saw, or at least always thought to see. The ones inside do not even notice if they see or not, therefore they would likewise not even notice if they were outside. The Pharisees guard the rules that demarcate inside from outside. Jesus who tries to bring the beggar and blind man back inside the community transgresses their rules. Don't the Pharisees however do the same thing by actively throwing the beggar out again, supposedly on the same day, violating their holy Shabbat, on which no one should do anything?

Who is from God? That is the question which hovers over the entire narrative. The question finds, in the end, no definite answer. The reader is now in charge to decide. Will he see or is he blinded by the new incidence of light? Does he live during the day or during the night?

As demonstrated, the old lines of demarcation are on the one hand sharply articulated by the various characters of this story, but at the same time blurred by the course of the narrative and its irregular (some would say: incoherent) attributions. The poles are brought closer together with that ambivalence, crossings are fostered and facilitated.

\section{The raising of Lazarus (John 11:1-45)}

As a second example, this time for metaphorical transgressions, we will consult one of the so-called I-Am-Sayings in John 11:25-26. This metaphor is placed in the context of the death of Lazarus. Lazarus' sister Martha reproaches the late-coming Jesus by saying: If you had been here, my brother would not have died (John 11:21), but Jesus reassures her: Your brother will rise again (John 11:23). She then mistakes this remark as a reference to the future resurrection at the last day. Jesus, now, responds with an interesting metaphor, I am the resurrection and the life. The one who believes in me will live, even though they die (v. 25) and he goes on and says, and whoever lives and believes in me will never die (v. 26). 
Jesus further asks Martha and at the same time the reader of the Gospel: Do you believe that? ${ }^{2}$ Later in the narrative we see that Martha does not really comprehend what Jesus was saying. She still tries to prevent Jesus from approaching the tomb of Lazarus (John 11:39).

The Johannine Jesus uses various metaphors throughout the Gospel: The bread of life, the good shepherd, light and darkness, the birth form above and so on. And the Gospel's inclination to metaphors and rich imagery is closely related to its revelatory content: God becomes flesh. The heavenly logos becomes flesh in metaphors, because no earthly expression could ever contain it. Metaphors can articulate thing that we can't grasp, that we can't touch nor see, that are beyond our earthly realm of time and space.

In these verses of John 11 about living though dying and living without dying we have a very special version of metaphor. A metaphor that makes one think unthinkable things. Hans Blumenberg calls these type of metaphors "explosive metaphors". For further explanation he refers to the following example stated by Nicholas of Cusa: "God is an infinite sphere whose centre is everywhere and circumference nowhere." (Liber 14 philosophorum, cited from (Blumenberg 2010: 124)) One can try to draw this kind of a circle in the head - a circle, whose centre is everywhere and circumference nowhere. At some point you have to dismiss this thought, because it would explode in your head.

Another example is this: Try to increase the diameter of a circle further and further until it is a line. The continuous redoubling of a circle's radius toward infinity would eventually deprive the circle of its circular characteristics, it will eventually become a line in the thinker's head. We simply cannot carry this metaphor to an end before it will explode.

John uses these explosive metaphors often. He starts a picture, which is easily imaginable, but suddenly introduces a twist, which causes us to squint, because we cannot follow the lines anymore. In this way he can depict phenomena that transcend our traditional categories of space

2 The theater scholar J Roselt describes this phenomenon as "doppelten Adressierung“ (doubled address) on stage, that allows for an internal communication between the characters on the one hand and an external communiaction between character and audience on the other hand (see Roselt [2014:68]). The same can be applied upon narratives (see Wagener [2015:158]). 
and time, while still depicting them in the categories of space and time. "The aim", as Blumenberg describes the explosive metaphor, "is to make transcendence something that can be 'experienced' as the limit of theoretical apprehension, and eo ipso as a challenge to heterogeneous apprehensive modes." (Blumenberg 2010: 123)

Precisely this metaphorical phenomenon is observable in the explanation of the I-Am-Saying in John 11. It seems feasible to imagine life even if you die, given that afterlife was a common vision in Early Judaism as well as Christianity (Zimmermann 2008: 76). But if we think about this afterlife without having to die beforehand (v. 26); or the other way around: If we think about the afterlife now with the prospect of still having to die (v. 25), we will not be able to carry this thought to an end. Our notion of finitude and eternal afterlife explodes. The common notion places eternal life after death. But how can we have eternal life just now, when we still must face the end of our time? That is what the explosive metaphor in John 11:25-26 teaches us to imagine, although we fail to imagine it up until the end. To put it in the words of Harold Attridge's instructive analysis of Johannine imagery: "What disturbs also tantalizes" (Attridge 2006: 50). It tantalizes, maybe agitates us for becoming active again, it provokes us to move and consequently rethink, review, reinterpret conventional lines of demarcation and separation. New contexts, new perspectives, new sensations and cognitions within well-known and comforting patterns can trigger an explosion of old segregating placements.

Even the ballad of Kipling does not end with the definite separation of east and west, but, as it is often ignored, by transcending them through a poetic image: But there is neither East nor West, Border, nor Breed, nor Birth, When two strong men stand face to face, tho' they come from the ends of the earth!

For Kipling the sharp demarcation of East and West and the seemingly insurmountable barriers between them are overcome whenever two equals encounter each other in person. Origin is not destiny.

In the Gospel of John a similarly dialectic aphorism is initially declared by John the Baptist: The one who comes from above is above all; the one who is from the earth belongs to the earth and speaks from the earth. Our provenance or even current stand determines our ways of speaking, 
seeing and thinking. But the Gospel of John also surmounts this sharp distinction between above and below by means of skilful non-linear narrative trajectories and the use of explosive metaphors. In the narrative of the healing of the man born blind (John 9:1-40) sharp dichotomies, such as sinners and those from God, blind ones and those who see, insiders and outsiders, are first introduced by the characters of the story, but then gradually blurred in the course of the narrative through inconsistent attributions.

In the narrative of the raising of Lazarus (John 11:1-45) the metaphorical I-Am-Saying of Jesus provokes the reader to transcend his or her regular boundaries between linear time and eternity, between life and death. The metaphor transfers eternity into this life, the above into the below. It provokes the reader to think beyond his or her familiar categories of linear time and three-dimensional space, so that there can be movement between above and below.

We will end our thoughts with a parable that combines by its very nature metaphorical and narrative elements (Zimmermann 2015a) (Zimmermann $2015 \mathrm{~b}$ ) and provokes us to answer the question of our origins and our natural habitat anew: From where do we speak? For this parable we will leave the Johannine dichotomy of earth and heaven, instead diving down into the deep waters of the sea with David Foster Wallace:

There are these two young fish swimming along, and they happen to meet an older fish swimming the other way, who nods at them and says, 'Morning, boys, how's the water?' And the two young fish swim on for a bit, and then eventually one of them looks over at the other and goes, "What the hell is water?" (Wallace 2009: 3-4)

\section{References}

Attridge HW [soon to be published]. Some Methodological Considerations Regarding John, Jesus, and History (lecture given at Princeton Theological Seminary 2016):1-40. 
Attridge HW 2006. The Cubist Principle in Johannine Imagery: John and the Reading of Images in Contemporary Platonism. In: Frey J, Van der Watt JG and Zimmermann R (eds). Imagery in the Gospel of John: Terms, Forms, Themes, and Theology of Johannine Figurative Language. Tübingen: Mohr Siebeck. 47-60.

Blumenberg H 2010. Paradigms for a Metaphorology: Translated from the German with an afterword by Robert Savage. Ithaca, N.Y: Cornell University Library.

Bultmann R 1959. Art. Johannesevangelium. Religion in Geschichte und Gegenwart (3. Aufl) Dritter Band: H-Kon: 840-850.

Estes D 2008. The Temporal Mechanics of the Fourth Gospel: A Theory of Hermeneutical Relativity in the Gospel of John. Leiden, Boston, Mass.: Brill.

Graeper M [soon to be published]. Bible and Apartheid: A Hermeneutical and Reception-Historical Study with a Contextual Reading of Matt 15:21-28.

Koschorke A 2013. Wahrheit und Erfindung: Grundzüge einer Allgemeinen Erzähltheorie. Frankfurt am Main: Fischer.

Parsenios GL 2010. Rhetoric and Drama in the Johannine Lawsuit Motif. Tübingen: Mohr Siebeck.

Popkes EE 2015. Jesus als der neue Tempel - Jn 2:19. In: Zimmermann R (ed.). Kompendium der Gleichnisse Jesu. Gütersloh: Gütersloher Verlagshaus. 711-718.

Ricoeur P 1992. Oneself as Another. Translated by K. Blamey. Chicago, Ill.: Univ. of Chicago Pr.

Ricoeur P 2009. Time and Narrative: Volume I. Translated by Lathleen McLaughling and David Pellauer. Chicago, Ill.: University of Chicago Press.

Roselt J 2014. Art. Dialog/ Monolog. In: Fischer-Lichte E, Kolesch D and Warstat M (eds). Metzler-Lexikon Theatertheorie. Stuttgart, Weimar: Metzler. 67-72. 
Wagener F 2015. Figuren als Handlungsmodelle: Simon Petrus, die samaritische Frau, Judas und Thomas als Zugänge zu einer narrativen Ethik des Johannesevangeliums. Tübingen: Mohr Siebeck.

Wallace DF 2009. This is Water: Some Thoughts, Delivered on a Significant Occasion about Living a Compassionate Life. New York: Little Brown.

Zimmermann R 2008. The Narrative Hermeneutics of John 11: Learning with Lazarus How to Understand Death, Life, and Resurrection. In: Koester CR and Bieringer R (eds). The Resurrection of Jesus in the Gospel of John. Tübingen: Mohr Siebeck. 75-101.

Zimmermann R (ed) 2015a. Kompendium der Gleichnisse Jesu. Gütersloh: Gütersloher Verlagshaus.

Zimmermann R 2015b. Puzzling the Parables of Jesus: Methods and Interpretation. Minneapolis: Fortress Press. 